Interdisciplinary Studies on Ancient Stone

Proceedings of the XI ASMOSIA Conference (Split 2015) 
Publishers:

ARTS ACADEMY IN SPLIT

UNIVERSITY OF SPLIT

and

UNIVERSITY OF SPLIT

FACULTY OF CIVIL ENGINEERING, ARCHITECTURE AND GEODESY

\author{
Technical editor: \\ Kate Bošković \\ English language editor: \\ Graham McMaster \\ Computer pre-press: \\ Nikola Križanac \\ Cover design: \\ Mladen Čulić
}

Cover page:

Sigma shaped mensa of pavonazzetto marble from Diocletian's palace in Split

ISBN 978-953-6617-49-4 (Arts Academy in Split)

ISBN 978-953-6116-75-1 (Faculty of Civil Engineering, Architecture and Geodesy)

e-ISBN 978-953-6617-51-7 (Arts Academy in Split)

e-ISBN 978-953-6116-79-9 (Faculty of Civil Engineering, Architecture and Geodesy)

CIP available at the digital catalogue of the University Library in Split, no 170529005 


\section{ASMOSIA XI \\ Interdisciplinary Studies of Ancient Stone}

Proceedings of the Eleventh International Conference of ASMOSIA, Split, 18-22 May 2015

Edited by

Daniela Matetić Poljak

Katja Marasović
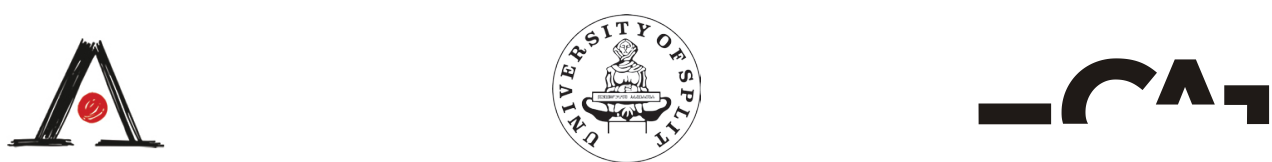

Split, 2018 


\section{Nota bene}

All papers are subjected to an international review.

The quality of the images relies on the quality of the originals provided by the authors. 


\section{APPLICATIONS TO SPECIFIC ARCHEOLOGICAL QUESTIONS - USE OF MARBLE}

Hermaphrodites and Sleeping or Reclining Maenads:

Production Centres and Quarry Marks

Patrizio Pensabene

First Remarks about the Pavement of the Newly Discovered Mithraeum of the Colored Marbles at Ostia and New Investigations on Roman and Late Roman White and Colored Marbles from Insula IV, IX Massimiliano David, Stefano Succi and Marcello Turci

Alabaster. Quarrying and Trade in the Roman World:

Evidence from Pompeii and Herculaneum

Simon J. Barker and Simona Perna

Recent Work on the Stone at the Villa Arianna and the Villa San Marco

(Castellammare di Stabia) and Their Context within the Vesuvian Area

Simon J. Barker and J. Clayton Fant

Marble Wall Decorations from the Imperial Mausoleum $\left(4^{\text {th }} \mathrm{C}\right.$. $)$ and the Basilica of San Lorenzo ( $5^{\text {th }}$ C.) in Milan: an Update on Colored Marbles in Late Antique Milan Elisabetta Neri, Roberto Bugini and Silvia Gazzoli

Sarcophagus Lids Sawn from their Chests

Dorothy H. Abramitis and John J. Herrmann

The Re-Use of Monolithic Columns in the Invention and Persistence of Roman Architecture

Peter D. De Staebler

The Trade in Small-Size Statues in the Roman Mediterranean:

a Case Study from Alexandria

Patrizio Pensabene and Eleonora Gasparini

The Marble Dedication of Komon, Son of Asklepiades, from Egypt:

Material, Provenance, and Reinforcement of Meaning

Patricia A. Butz

Multiple Reuse of Imported Marble Pedestals at Caesarea Maritima in Israel

Barbara Burrell

Iasos and Iasian Marble between the Late Antique and Early Byzantine Eras

Diego Peirano 
Thassos, Known Inscriptions with New Data

Tony Kozelj and Manuela Wurch-Kozelj

The Value of Marble in Roman Hispalis: Contextual, Typological and Lithological Analysis of an Assemblage of Large Architectural Elements Recovered at No 17 Goyeneta Street (Seville, Spain)

Ruth Taylor, Oliva Rodríguez, Esther Ontiveros, María Luisa Loza, José Beltrán and Araceli Rodríguez

Giallo Antico in Context. Distribution, Use and Commercial Actors According

to New Stratigraphic Data from the Western Mediterranean $\left(2^{\text {nd }} \mathrm{C} . \mathrm{Bc}-\right.$ Late $1^{\text {st }} \mathrm{C}$. Ad $)$

Stefan Ardeleanu

Amethystus: Ancient Properties and Iconographic Selection

Luigi Pedroni

\section{PROVENANCE IDENTIFICATION I: (MARBLE)}

Unraveling the Carrara - Göktepe Entanglement

Walter Prochaska, Donato Attanasio and Matthias Bruno

The Marble of Roman Imperial Portraits

Donato Attanasio, Matthias Bruno, Walter Prochaska and Ali Bahadir Yavuz

Tracing Alabaster (Gypsum or Anhydrite) Artwork Using Trace Element Analysis

and a Multi-Isotope Approach ( $\mathrm{Sr}, \mathrm{S}, \mathrm{O})$

Lise Leroux, Wolfram Kloppmann, Philippe Bromblet, Catherine Guerrot,

Anthony H. Cooper, Pierre-Yves Le Pogam, Dominique Vingtain and Noel Worley

Roman Monolithic Fountains and Thasian Marble

Annewies van den Hoek, Donato Attanasio and John J. Herrmann

Archaeometric Analysis of the Alabaster Thresholds of Villa A, Oplontis

(Torre Annunziata, Italy) and $\mathrm{New} \mathrm{Sr}$ and $\mathrm{Pb}$ Isotopic Data for

Alabastro Ghiaccione del Circeo

Simon J. Barker, Simona Perna, J. Clayton Fant, Lorenzo Lazzarini and Igor M. Villa

Roman Villas of Lake Garda and the Occurrence of Coloured Marbles in the Western Part of "Regio X Venetia et Histria" (Northern Italy)

Roberto Bugini, Luisa Folli and Elisabetta Roffia

Calcitic Marble from Thasos in the North Adriatic Basin:

Ravenna, Aquileia, and Milan

John J. Herrmann, Robert H. Tykot and Annewies van den Hoek

Characterisation of White Marble Objects from the Temple of Apollo and the House of Augustus (Palatine Hill, Rome)

Francesca Giustini, Mauro Brilli, Enrico Gallocchio and Patrizio Pensabene

Study and Archeometric Analysis of the Marble Elements Found in the Roman Theater at Aeclanum (Mirabella Eclano, Avellino - Italy)

Antonio Mesisca, Lorenzo Lazzarini, Stefano Cancelliere and Monica Salvadori 
Two Imperial Monuments in Puteoli:

Use of Proconnesian Marble in the Domitianic and Trajanic Periods in Campania

Irene Bald Romano, Hans Rupprecht Goette, Donato Attanasio and Walter Prochaska

Coloured Marbles in the Neapolitan Pavements ( $16^{\text {th }}$ And $17^{\text {th }}$ Centuries):

the Church of Santi Severino e Sossio

Roberto Bugini, Luisa Folli and Martino Solito

Roman and Early Byzantine Sarcophagi of Calcitic Marble from Thasos in Italy:

Ostia and Siracusa

Donato Attanasio, John J. Herrmann, Robert H. Tykot and Annewies van den Hoek

Revisiting the Origin and Destination of the Late Antique Marzamemi

'Church Wreck' Cargo

Justin Leidwanger, Scott H. Pike and Andrew Donnelly....

The Marbles of the Sculptures of Felix Romuliana in Serbia

Walter Prochaska and Maja Živić

Calcitic Marble from Thasos and Proconnesos in Nea Anchialos (Thessaly)

and Thessaloniki (Macedonia)

Vincent Barbin, John J. Herrmann, Aristotle Mentzos and Annewies van den Hoek

Architectural Decoration of the Imperial Agora's Porticoes at Iasos

Fulvia Bianchi, Donato Attanasio and Walter Prochaska

The Winged Victory of Samothrace - New Data on the Different Marbles

Used for the Monument from the Sanctuary of the Great Gods

Annie Blanc, Philippe Blanc and Ludovic Laugier

Polychrome Marbles from the Theatre of the Sanctuary of Apollo Pythios

in Gortyna (Crete)

Jacopo Bonetto, Nicolò Mareso and Michele Bueno

Paul the Silentiary, Hagia Sophia, Onyx, Lydia, and Breccia Corallina

John J. Herrmann and Annewies van den Hoek

Incrustations from Colonia Ulpia Traiana (Near Modern Xanten, Germany)

Vilma Ruppienè and Ulrich Schüssler

Stone Objects from Vindobona (Austria) - Petrological Characterization and Provenance of Local Stone in a Historico-Economical Setting

Andreas Rohatsch, Michaela Kronberger, Sophie Insulander,

Martin Mosser and Barbara Hodits

Marbles Discovered on the Site of the Forum of Vaison-la-Romaine (Vaucluse, France):

Preliminary Results

Elsa Roux, Jean-Marc Mignon, Philippe Blanc and Annie Blanc

Updated Characterisation of White Saint-Béat Marble. Discrimination Parameters

from Classical Marbles

Hernando Royo Plumed, Pilar Lapeunte, José Antonio Cuchí,

Mauro Brilli and Marie-Claire Savin 
Grey and Greyish Banded Marbles from the Estremoz Anticline in Lusitania

Pilar Lapuente, Trinidad Nogales-Basarrate, Hernando Royo Plumed,

Mauro Brilli and Marie-Claire Savin

New Data on Spanish Marbles: the Case of Gallaecia (NW Spain)

Anna Gutiérrez Garcia-M., Hernando Royo Plumed and Silvia González Soutelo

A New Roman Imperial Relief Said to Be from Southern Spain:

Problems of Style, Iconography, and Marble Type in Determining Provenance

John Pollini, Pilar Lapuente, Trinidad Nogales-Basarrate and Jerry Podany

Reuse of the Marmora from the Late Roman Palatial Building at Carranque

(Toledo, Spain) in the Visigothic Necropolis

Virginia García-Entero, Anna Gutiérrez Garcia-M. and Sergio Vidal Álvarez

Imperial Porphyry in Roman Britain

David F. Williams

Recycling of Marble: Apollonia/Sozousa/Arsuf (Israel) as a Case Study

Moshe Fischer, Dimitris Tambakopoulos and Yannis Maniatis

Thasian Connections Overseas: Sculpture in the Cyrene Museum (Libya)

Made of Dolomitic Marble from Thasos

John J. Herrmann and Donato Attanasio

Marble on Rome's Southwestern Frontier: Thamugadi and Lambaesis

Robert H. Tykot, Ouahiba Bouzidi, John J. Herrmann and Annewies van den Hoek

Marble and Sculpture at Lepcis Magna (Tripolitania, Libya):

a Preliminary Study Concerning Origin and Workshops

Luisa Musso, Laura Buccino, Matthias Bruno, Donato Attanasio and Walter Prochaska

The Pentelic Marble in the Carnegie Museum of Art Hall of Sculpture,

Pittsburgh, Pennsylvania

Albert D. Kollar

Analysis of Classical Marble Sculptures in the Michael C. Carlos Museum,

Emory University, Atlanta

Robert H. Tykot, John J. Herrmann, Renée Stein, Jasper Gaunt,

Susan Blevins and Anne R. Skinner.

\section{PROVENANCE IDENTIFICATION II: (OTHER STONES)}

Aphrodisias and the Regional Marble Trade. The Scaenae Frons of the Theatre at Nysa

Natalia Toma

The Stones of Felix Romuliana (Gamzigrad, Serbia)

Bojan Djurić, Divna Jovanović, Stefan Pop Lazić and Walter Prochaska

Aspects of Characterisation of Stone Monuments from Southern Pannonia

Branka Migotti 
The Budakalász Travertine Production

Stone Monuments from Carnuntum and Surrounding Areas (Austria) Petrological Characterization and Quarry Location in a Historical Context

Espejón Limestone and Conglomerate (Soria, Spain):

Archaeometric Characterization, Quarrying and Use in Roman Times

Virginia García-Entero, Anna Gutiérrez Garcia-M, Sergio Vidal Álvarez,

María J. Peréx Agorreta and Eva Zarco Martínez

The Use of Alcover Stone in Roman Times (Tarraco, Hispania Citerior).

Contributions to the Officina Lapidaria Tarraconensis

Diana Gorostidi Pi, Jordi López Vilar and Anna Gutiérrez Garcia-M.

\section{ADVANCES IN PROVENANCE TECHNIQUES,} METHODOLOGIES AND DATABASES

Grainautline - a Supervised Grain Boundary Extraction Tool

Supported by Image Processing and Pattern Recognition

Kristóf Csorba, Lilla Barancsuk, Balázs Székely and Judit Zöldföldi

A Database and GIS Project about Quarrying, Circulation and Use of Stone

During the Roman Age in Regio X - Venetia et Histria.

The Case Study of the Euganean Trachyte

Caterine Previato and Arturo Zara

\section{QUARRIES AND GEOLOGY}

The Distribution of Troad Granite Columns as Evidence for Reconstructing the Management of Their Production

Patrizio Pensabene, Javier Á. Domingo and Isabel Rodà

Ancient Quarries and Stonemasonry in Northern Choria Considiana

Hale Güney

Polychromy in Larisaean Quarries and its Relation to Architectural Conception

Gizem Mater and Ertunç Denktaş

Euromos of Caria: the Origin of an Hitherto Unknown Grey Veined Stepped Marble of Roman Antiquity

Matthias Bruno, Donato Attanasio, Walter Prochaska and Ali Bahadir Yavuz

Unknown Painted Quarry Inscriptions from Bacakale at Docimium (Turkey)

Matthias Bruno

The Green Schist Marble Stone of Jebel El Hairech (North West of Tunisia):

a Multi-Analytical Approach and its Uses in Antiquity

Ameur Younès, Mohamed Gaied and Wissem Gallala

Building Materials and the Ancient Quarries at Thamugadi (East of Algeria),

Case Study: Sandstone and Limestone

Younès Rezkallah and Ramdane Marmi 
The Local Quarries of the Ancient Roman City of Valeria (Cuenca, Spain)

Javier Atienza Fuente

The Stone and Ancient Quarries of Montjuïc Mountain (Barcelona, Spain)

Aureli Álvarez

Notae Lapicidinarum: Preliminary Considerations about the Quarry Marks

from the Provincial Forum of Tarraco

Maria Serena Vinci

The Different Steps of the Rough-Hewing on a Monumental Sculpture

at the Greek Archaic Period: the Unfinished Kouros of Thasos

Danièle Braunstein

A Review of Copying Techniques in Greco-Roman Sculpture

Séverine Moureaud

Labour Forces at Imperial Quarries

Ben Russell

Social Position of Craftsmen inside the Stone and Marble Processing Trades

in the Light of Diocletian's Edict on Prices

Krešimir Bosnić and Branko Matulić

6. STONE PROPERTIES, WEATHERING EFFECTS AND RESTORATION,

AS RELATED TO DIAGNOSIS PROBLEMS, MATCHING

OF STONE FRAGMENTS AND AUTHENTICITY

Methods of Consolidation and Protection of Pentelic Marble

Maria Apostolopoulou, Elissavet Drakopoulou, Maria Karoglou and Asterios Bakolas

\section{PIGMENTS AND PAINTINGS ON MARBLE}

Painting and Sculpture Conservation in Two Gallo-Roman Temples in Picardy (France):

Champlieu and Pont-Sainte-Maxence

Véronique Brunet-Gaston and Christophe Gaston

The Use of Colour on Roman Marble Sarcophagi

Eliana Siotto

New Evidence for Ancient Gilding and Historic Restorations on a Portrait of Antinous in the San Antonio Museum of Art

Jessica Powers, Mark Abbe, Michelle Bushey and Scott H. Pike

Schists and Pigments from Ancient Swat (Khyber Pukhtunkhwa, Pakistan)

Francesco Mariottini, Gianluca Vignaroli, Maurizio Mariottini and Mauro Roma

8. SPECIAL THEME SESSION: „THE USE OF MARBLE AND LIMESTONE IN THE ADRIATIC BASIN IN ANTIQUITY"

Marble Sarcophagi of Roman Dalmatia Material - Provenance - Workmanship

Guntram Koch 
Funerary Monuments and Quarry Management in Middle Dalmatia

Marble Revetments of Diocletian's Palace

Katja Marasović and Vinka Marinković

The Use of Limestones as Construction Materials for the Mosaics of Diocletian's Palace

Branko Matulić, Domagoj Mudronja and Krešimir Bosnić

Restoration of the Peristyle of Diocletian's Palace in Split

Goran Nikšić

Marble Slabs Used at the Archaeological Site of Sorna near Poreč Istria - Croatia

Đeni Gobić-Bravar

Ancient Marbles from the Villa in Verige Bay, Brijuni Island, Croatia

Mira Pavletić and Đeni Gobić-Bravar

Notes on Early Christian Ambos and Altars in the Light of some Fragments

from the Islands of Pag and Rab

Mirja Jarak

The Marbles in the Chapel of the Blessed John of Trogir

in the Cathedral of St. Lawrence at Trogir

Đeni Gobić-Bravar and Daniela Matetić Poljak

The Use of Limestone in the Roman Province of Dalmatia

Edisa Lozić and Igor Rižnar

The Extraction and Use of Limestone in Istria in Antiquity

Klara Buršić-Matijašić and Robert Matijašić

Aurisina Limestone in the Roman Age:

from Karst Quarries to the Cities of the Adriatic Basin

Caterina Previato

The Remains of Infrastructural Facilities

of the Ancient Quarries on Zadar Islands (Croatia)

Mate Parica

The Impact of Local Geomorphological and Geological Features

of the Area for the Construction of the Burnum Amphitheatre

Miroslav Glavičić and Uroš Stepišnik

Roman Quarry Klis Kosa near Salona

Ivan Alduk

Marmore Lavdata Brattia

Miona Miliša and Vinka Marinković

Quarries of the Lumbarda Archipelago

Ivka Lipanović and Vinka Marinković 
Island of Korčula - Importer and Exporter of Stone in Antiquity

Mate Parica and Igor Borzić

Faux Marbling Motifs in Early Christian Frescoes

in Central and South Dalmatia: Preliminary Report

Tonči Borovac, Antonija Gluhan and Nikola Radošević 


\title{
THE USE OF ALCOVER STONE IN ROMAN TIMES (TARRACO, HISPANIA CITERIOR). CONTRIBUTIONS TO THE OFFICINA LAPIDARIA TARRACONENSIS
}

\author{
Diana Gorostidi Pi ${ }^{1}$, Jordi López Vilar ${ }^{2}$ and Anna Gutiérrez Garcia-M. ${ }^{3}$ \\ ${ }^{1}$ Institut Català d’Arqueologia Clàssica (ICAC) / Universitat Rovira i Virgili, Tarragona, Spain (dgorostidi@icac.cat) \\ ${ }^{2}$ Institut Català d’Arqueologia Clàssica (ICAC), Tarragona, Spain (jlopez@icac.cat) \\ ${ }^{3}$ Institut de Recherche sur les ArchéoMATériaux (IRAMAT) / Centre de Recherche en Physique Appliquée à \\ l'Archéologie (CRP2A) / Université de Bordeaux Montaigne, France (anna.gutierrez@u-bordeaux-montaigne.fr)
}

\begin{abstract}
After the recent re-edition of Tarraco's epigraphic corpus $(\mathrm{CIL} \mathrm{II} / 14)$, we initiated a multidisciplinary project to study the stones used for the town's inscriptions. The study of Santa Tecla stone and the knowledge of the quarries of the territory provides a basis for the study of stone from Alcover, which was employed during the founding period of the colonia. Its lithology is very different from the bioclastic limestones and calcarenites so common around Tarragona that supplied large blocks and ashlars (El Mèdol and soldó stones) and facilitates obtaining uniform, thin pieces perfect for plaques. Its use for the earliest epigraphy is one of the clearest pieces of evidence to date the first historic urban phases. Alcover stone was used alongside another local stone, Santa Tecla limestone, which was gradually introduced during Augustan and Julio-Claudian times. However, in Flavian times, Alcover stone was no longer used in epigraphy.
\end{abstract}

Keywords

Tarraco, Alcover stone, Roman inscriptions

\section{Introduction}

Updating of the recently re-edited epigraphic corpus $^{1}$ is a key element in a multidisciplinary project aiming at understanding the stones used for the inscriptions of Tarraco (Hispania Tarraconensis). ${ }^{2}$ After a study of Santa Tecla

\section{$1 \quad \mathrm{CIL} \mathrm{II}^{2} / 14,2-4$.}

2 This paper based on the preliminary results from the ongoing R\&D Research project "Officinae lapidariae Tarraconenses. Canteras, talleres y producciones artísticas en piedra de la Provincia Tarraconensis" (I+D HAR2015-65379-P (MINECO/FEDER, UE)), funded

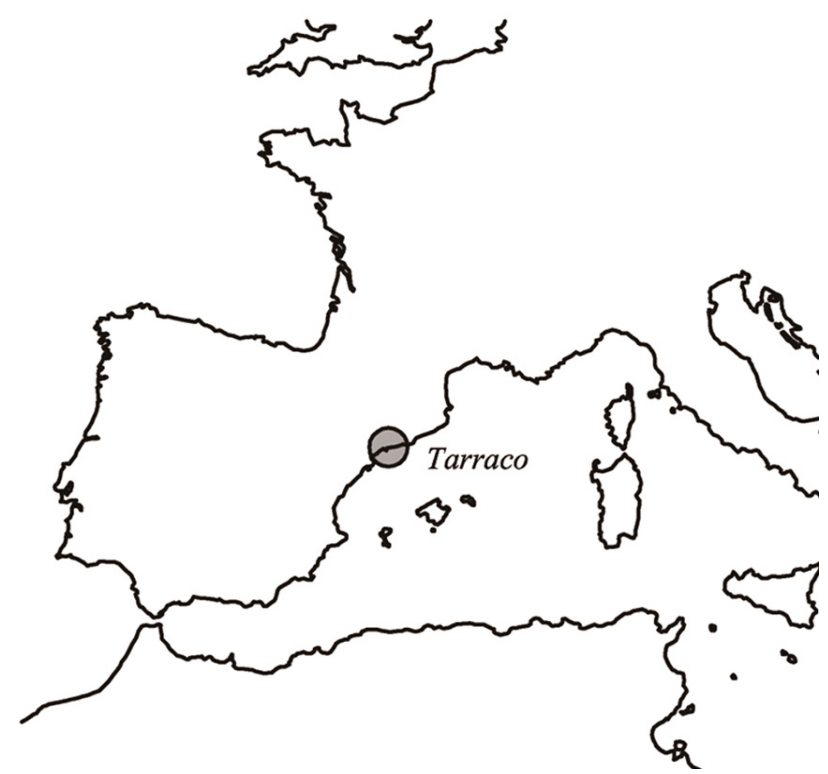

Fig. 1. Tarraco in the western Mediterranean context

stone $^{3}$ and after advances in our knowledge of the quarries of the territory of Tarragona, ${ }^{4}$ (Fig. 1) we now tackle the study of a material employed during the earliest period of the town: Alcover stone. Its lithology is very different from the bioclastic limestones and calcarenites (El Mèdol and soldó stones) that supplied Tarraco with large blocks and ashlars; its structure makes it possible to obtain uniform, thin slabs, which are perfect for plaques. No archaeological evidence at the Alcover quarries sheds light on the beginning or the end of exploitation there, but fortuitous ceramic findings in

by the Ministerio de Ciencia e Innovación of the Gobierno de España. We want to thank J.A. Remolà, curator of the MNAT, and archaeologists J.F. Roig (ICAC) and J. Massó (Institut Municipal de Museus de Reus), for helping and facilitating our research.

4 GUTIÉRREZ GARCIA-M. 2009; 2011. 

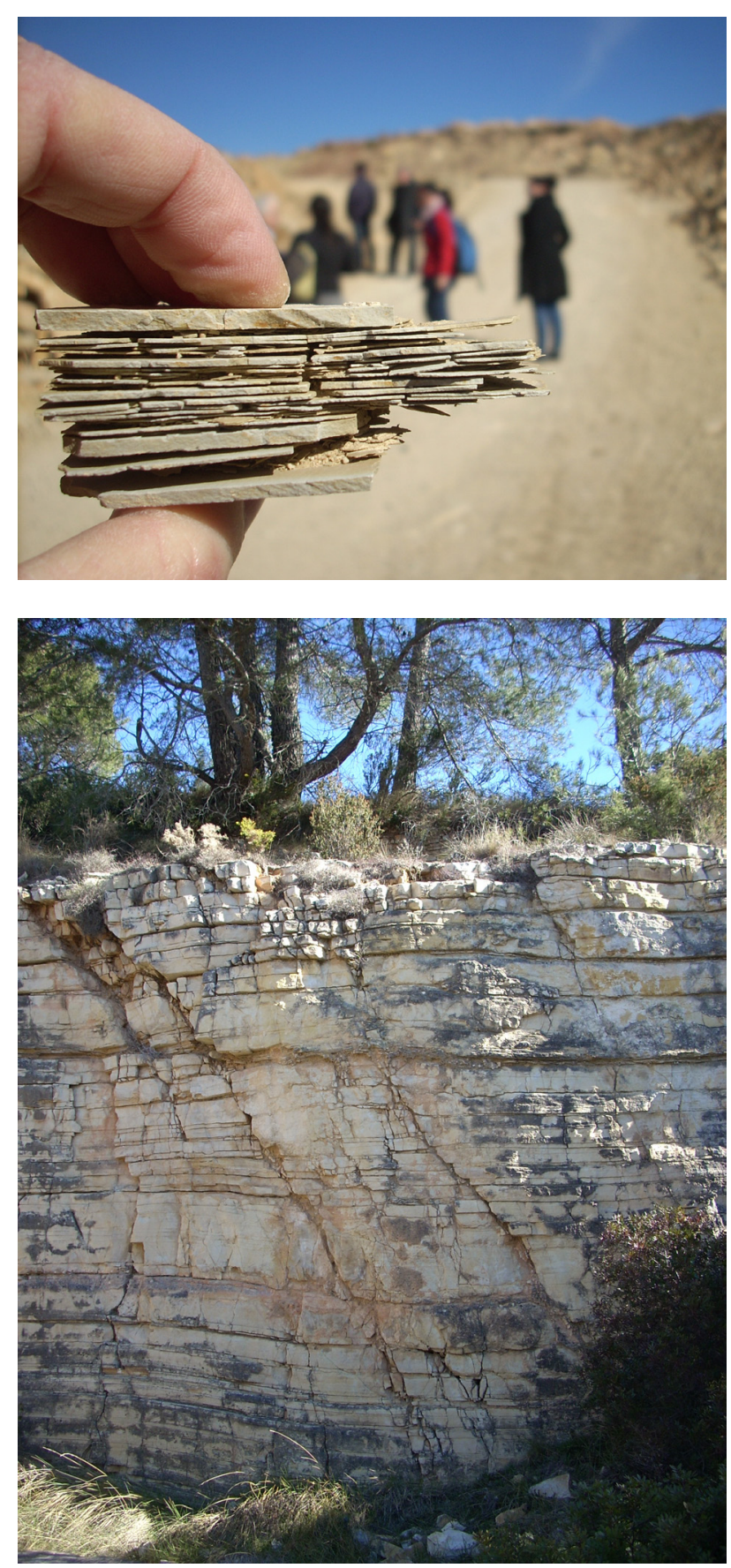

Fig. 2. Two examples of the strong bedding of Alcover stone outcrops. A: millimetric/centimetric and B: decimetric bedding (photos: authors)

the quarries have demonstrated the Roman presence at least during the $1^{\text {st }}-2^{\text {nd }}$ centuries $\mathrm{AD} .^{5}$

Epigraphy, which provides well-dated inscriptions, is crucial to delineate the chronology of the stone's extraction and use; in this case, its start in the early $1^{\text {st }}$ century BC. In fact, the use of Alcover stone in the earliest epigraphy of Tarraco, as in the honorific inscriptions commemorating the foundation of the colonia in Caesar's time, provides solid evidence to advance our knowledge of the first historic phases of the town. ${ }^{6}$

\section{Characteristics of Alcover stone}

Alcover stone is a sedimentary carbonate rock formed during the Middle Triassic in a shallow lagoon of calm water connected to the Sea of Tethys through a coral reef that restricted the entrance of seawater. These particular conditions created a context in which the continuous sedimentation of very fine particles at the bottom of this lagoon produced this fine-grained stone in which various fossils have been perfectly preserved. It belongs to the Upper Muschelkalk ${ }^{7}$ and is a very homogeneous and very fine-grained stone with strong bedding, which results in the natural splitting of the rock into sheets between a few millimetres and $10 \mathrm{~cm}$ thick (Fig. 2). ${ }^{8}$ Macroscopically it is a compact, grey to light brown, almost beige, calcareous mudstone. Sometimes it may have a red colour which has occasionally led to erroneous identifications with red-toned marmora (Fig. 3). ${ }^{9}$

\section{The epigraphic survey}

An epigraphic survey was carried out in spring 2015 by revisiting and updating a previous work of J. F. Roig; this was the sole study until now of inscriptions on Alcover stone and it included 25 entries. ${ }^{10}$ Despite its usefulness, a new appraisal was done because of additional archaeological findings; some important pieces led to general considerations about the stone's use.

Thirty-six Latin inscriptions in CIL $\mathrm{II}^{2} / 14$ are listed as being made of Alcover stone. We excluded three of them because of erroneous information and we registered two as post-classical. We examined 51 inscriptions autoptically, most of which are currently in the warehouse of the archaeological museum. ${ }^{11}$ Fifteen inscriptions still

ALFÖLDY 2000; 2011, 430.

RIBA ARDERIU 1997.

8 GUTIÉRREZ GARCIA-M. 2009, 224.

9 Such as in the case of the inscription CIL $\mathrm{II}^{2} / 14,977$, a dedication to Cn. Domitius Calvinus (36 BC) (Fig. 3A).

10 ROIG 2001. Roig provides a useful list of inscriptions in Alcover stone, but his main goal is updating the archaeological data about the quarries and their exploitation in ancient times, and consequently the paper lacks a deeper analysis about the use, function and chronology of the inscriptions.

11 The National Archaeological Museum of Tarragona (MNAT). 

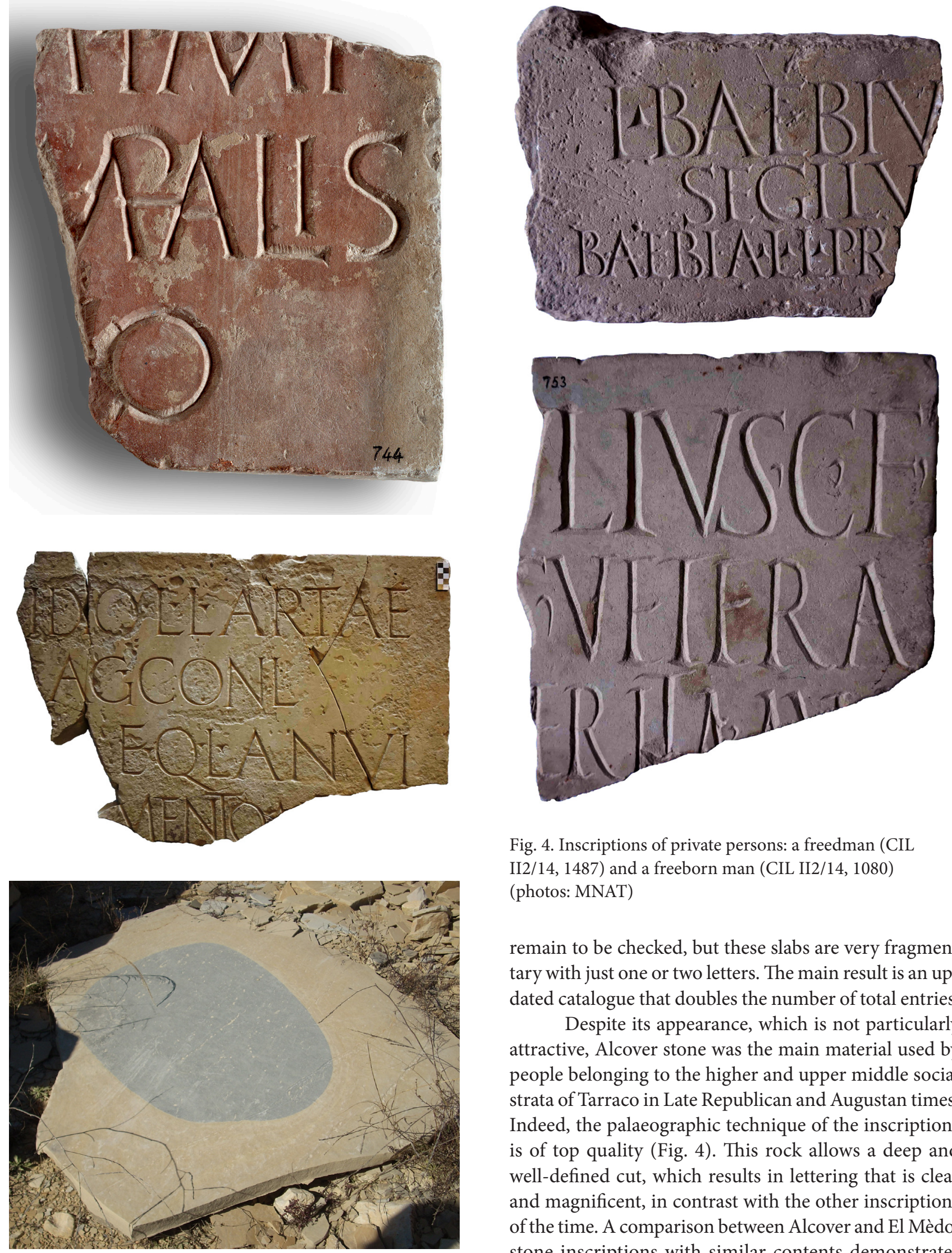

Fig. 4. Inscriptions of private persons: a freedman (CIL II2/14, 1487) and a freeborn man (CIL II2/14, 1080) (photos: MNAT)

remain to be checked, but these slabs are very fragmentary with just one or two letters. The main result is an updated catalogue that doubles the number of total entries.

Despite its appearance, which is not particularly attractive, Alcover stone was the main material used by people belonging to the higher and upper middle social strata of Tarraco in Late Republican and Augustan times. Indeed, the palaeographic technique of the inscriptions is of top quality (Fig. 4). This rock allows a deep and well-defined cut, which results in lettering that is clear and magnificent, in contrast with the other inscriptions of the time. A comparison between Alcover and El Mèdol stone inscriptions with similar contents demonstrates great differences in style and appearance.

Epigraphic practice for public tributes to Roman (due to fire) (CIL II2/14, 977), B: beige (CIL II2/14, 1270) and $\mathrm{C}$ : a case of combination of two tones in the same slab (photo: authors) magistrates in Republican times at Tarraco shows that local magistrates, prominent members of the municipal 


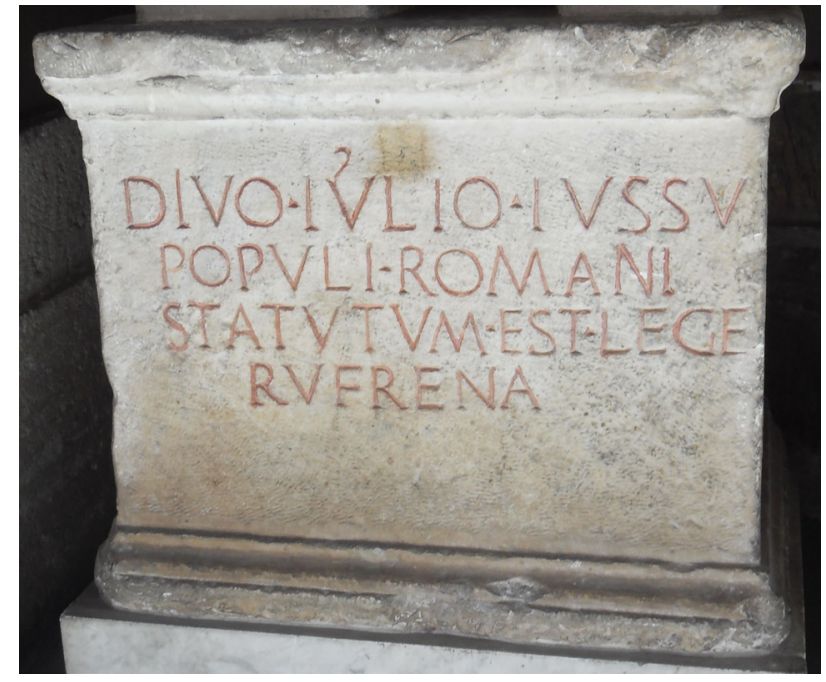

Fig. 5. Inscription of Divus Iulius from Otriculum (CIL VI, 872 = CIL I, 797) (photo: EDCS/M. Clauss)

society and wealthy private individuals preferred local Alcover stone for public as well as private inscriptions.

This preference was also connected with a specific workshop of carvers, which seems to have had connections with Italy. An inscription of Divus Iulius from Otricoli ${ }^{12}$ (Fig. 5) dated to $42 \mathrm{BC}$ shows a specific feature that is only known in another case from Tarraco: the dedication to P. Mucius Scaevola ${ }^{13}$ (45/44 BC), in a reused slab with a previous inscription for $\mathrm{Cn}$. Pompeius Magnus on the back $^{14}$ (71 BC) (Fig. 6). The characteristic hook-shaped apex attached to the letter $\mathrm{V}^{15}$ confirms the chronology of both inscriptions and testifies to a workshop connection. The palaeographic parallel from Italy highlights the importance of epigraphy as dating element for the use of Alcover stone at Tarraco, and as evidence for the arrival of Italic stonecutters in Hispania at this time. ${ }^{16}$

This preference for Alcover stone in elite epigraphy contrasts clearly with the use of other local limestones, among them El Mèdol stone, which was mostly used for structural purposes. For instance, El Mèdol stone appears in funerary buildings and in parallelepiped blocks that contain private epitaphs. ${ }^{17}$ These monuments belonged mainly to ordinary people, freeborn people, freedmen and slaves. According to the palaeography, onomastics and formulae, they date from the first century $\mathrm{BC}$ to the

CIL VI, 872 = CIL I, 797

CIL II²/14, 991.

GORDON 1983, 97.
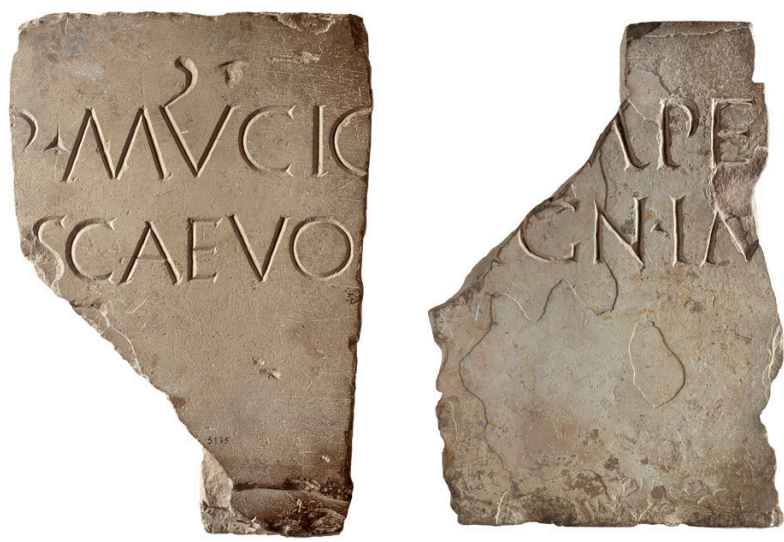

Fig. 6. Opistographic inscription from Tarraco (CIL II2/14, 991-988) (photos: MNAT)

Augustan age. This type of Mèdol epitaph characterizes the Republican epigraphy of Tarraco and disappears in the first decades of the $1^{\text {st }}$ century AD. ${ }^{18}$

Alcover stone was also used alongside Tarraco marble (Santa Tecla limestone), a fine easily workable stone that is characterized by a bright yellowish colour and occasionally a rosy tone. In contrast to the Alcover and Mèdol types, Santa Tecla stone stands out for its beauty and, in fact, its use gradually increased in Augustan and JulioClaudian times. ${ }^{19}$ The earliest inscription in Santa Tecla stone is a dedication to Tiberius dated to $16-14 \mathrm{BC},{ }^{20}$ and it could represent the beginning of the exploitation of this limestone, which was a prestigious local material reserved for the most elite commissions. During the Julio-Claudian period, Alcover stone is well documented as an epigraphic support, but its presence had diminished by the end of the century, at the time of the urbanistic reforms under the Flavians. These changes involved a massive exploitation of Santa Tecla stone as a favourite local building and ornamental material alongside the newly imported Luna (modern Carrara) marble. ${ }^{21}$ The Santa Tecla stone quarries continued to be heavily exploited from this period onwards.

At the same time, a change of technique took place in Flavian times when the officina lapidaria began to favour new epigraphic monuments in the shape of

For characteristics and formulae in the Republican epigraphy of Hispania, $c f$. DÍAZ ARIÑO 2008.

For private uses in the early Julio-Claudian period: (CIL II²/14, 1270; 1620 a-b). A slab containing a dedication to the Victoria Augusta offered by the colonia Tarraconensium seems to be the newest public inscription in Alcover stone (CIL II $\left.{ }^{2}, 14,864\right)$. 


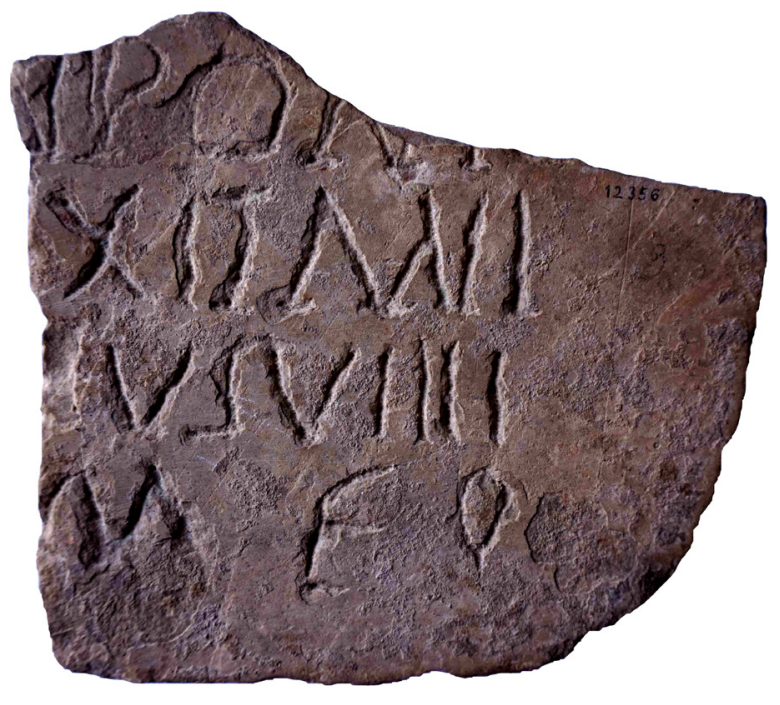

Fig. 7. Slab with an epitaph from the $4^{\text {th }}-5^{\text {th }}$ centuries (CIL II2/14, 1603) (photos: authors)

parallelepiped blocks, a kind of support that previously only stones similar to El Mèdol were capable of providing. As previously noted, archaeology does not offer evidence of when the Alcover quarries were abandoned, but one can have some confidence that their stone was gradually replaced by Santa Tecla and other minor local limestones - among them the so-called "llisós"- until its total disappearance from the epigraphic record. ${ }^{22}$

In fact, Flavian workshops specialized in producing a support that became common in the town: the tripartite monolithic pedestals elaborated in Santa Tecla stone. This type was widespread on the whole conventus Tarraconensis, at the expense of the characteristic inscribed plaques of the Julio-Claudian era. ${ }^{23}$ This phenomenon occurred simultaneously with the important urbanistic developments in the upper part of the town under the Flavian dynasty.

\section{Brief considerations}

Alcover stone went out of use for inscriptions after the Julio-Claudian period until Late Roman times, when inscriptions of the $4^{\text {th }}$ to $6^{\text {th }}$ centuries testify to its use once more (Fig. 7). As we have tried to demonstrate, the reason behind this chronological gap lies in the introduction of the local Santa Tecla stone as well as in

About "llisós" and its geological association with Santa Tecla stone, $c f$. GUTIÉRREZ GARCIA-M. 2009, 208-221.

Santa Tecla stone is diffused out of Tarraco in various ornamental purposes. For example, the honorific tripartite pedestals of the Flavian officina in Barcino and its territorium, Egara, Sigarra and Ilerda are well documented ( $c f$. ÁLVAREZ et al. 2009, 71-80). the massive arrival at Tarraco of other types of marble in Flavian times. ${ }^{24}$ This promoted a change in epigraphic practices, involving the privileged use of monolithic blocs and the monumental inscriptions in marble from Luna, the imperial marble par excellence. ${ }^{25}$

In this sense, assembling the Roman inscriptions of Tarraco creates an attractive epigraphic landscape composed according to the principles of Late Republican, $\mathrm{Au}$ gustan and Julio-Claudian aesthetics. The use of Alcover stone as a prestigious support for official monuments derives from previous traditions, but the palaeography reveals the arrival of craftsmen from Italy, who introduced the practice of institutional epigraphy of quality. ${ }^{26}$

In conclusion, the detailed exam of the inscriptions enables the identification of a hierarchy of the use of all these stones; in this hierarchy, Alcover stone is consigned to private uses after Late Republican times through the Julio-Claudian period and gives way to foreign, prestigious marbles and the above-mentioned Santa Tecla stone. Its complete disappearance in the epigraphic record coincides with a change of technique of the officina lapidaria. The workshops from the following period were specialized in making a new kind of support that would become the most common in the town: the tripartite pedestals in Santa Tecla stone. This typology was largely widespread on the whole of the conventus Tarraconensis, at the expense of the previously common plaques. This phenomenon occurred simultaneously with important urbanistic changes that were undertaken in Flavian times.
ÁLVAREZ et al. 2009, 81-82.

GUTIÉRREZ GARCIA-M, RODÀ 2012 RUÍZ RODRÍGUEZ 2016.

Cf. GOROSTIDI, LÓPEZ VILAR 2015. 


\section{REFERENCES}

ALFÖLDY G. 2000: "Wann wurde Tarraco römische Kolonie?”, in G. PACI (ed.): Epigraphai. Miscellanea epigrafica in onore di Lidio Gasperini, Tivoli, 3-22.

ALFÖLDY G. 2011: “Officina lapidaria Tarraconensis”, in A. DONATI, G. POMA (eds.): L' officina epigrafica romana. In ricordo di Giancarlo Susini, Faenza, 429-471.

ÁLVAREZ A., GARCÍA-ENTERO V., GUTIÉRREZ GARCIA-MORENO A., RODÀ I. 2009: El marmor de Tarraco. Explotació, utilització i comercialització de la pedra de Santa Tecla en època romana / Tarraco marmor. The Quarrying, Use and Trade of Santa Tecla Stone in Roman Times, Tarragona.

CIL II2/14 = ALFÖLDY G., Inscriptiones Hispaniae Latinae. Pars XIV Conventus Tarraconensis. Colonia Iulia urbs triumphalis Tarraco, Berlin, 2011-2012.

DÍAZ ARIÑO B. 2008: Epigrafía latina republicana de Hispania, Barcelona.

GORDON A. E. 1983: Illustrated introduction to Latin Epigraphy, Berkeley-Los Angeles-London.

GOROSTIDI D., LÓPEZ VILAR J. 2015: "La officina lapidaria Tarraconense en época augustea: actualización del corpus y primeras consideraciones", in LÓPEZ VILAR, J. (ed): Actes de 2on Congrés Internacional d'Arqueologia i Món Antic Tarraco Biennal. August i les províncies occidentals. 2000 aniversari de la mort d'August (Tarragona, 26-29 de novembre de 2014), Tarragona, 257-262.
GUTIÉRREZ GARCIA-MORENO A. 2009: Roman Quarries in the Northeast of Hispania (Modern Catalonia), Tarragona.

GUTIÉRREZ GARCIA-MORENO A. 2011: “The exploitation of local stone in Roman times: the case of north-eastern Spain”, World Archaeology 43 (2), 318-341.

GUTIÉRREZ GARCIA-M. A., RODÀ I. 2012: "El mármol de Luni-Carrara en la fachada mediterránea de Hispania", in KEAY, S. (ed.) Rome, Portus and the Mediterranean. London, Oxbow Books, 293-312.

MASSÓ J., ROIG J. F. 2004: "Notes sobre un lot de gerres de ceràmica trobat a la pedrera de la Lloera", Butlletí del Centre d'Estudis Alcoverencs 107, 13-19.

MNAT = Museu Nacional Arqueològic de Tarragona

RIBA ARDERIU O. (dir.) 1997: Diccionari de Geologia, Enciclopèdia Catalana, Barcelona.

ROIG J. F. 2001: “Inscripcions romanes sobre pedra d'Alcover", Butlletí del Centre d'Estudis Alcoverencs 95, 22-46.

RUÍZ RODRÍGUEZ J. C. 2016: “El uso del mármol lunense en la epigrafía de ámbito público. El caso de Tarraco en época altoimperial (siglos I y II n.e.)", Cuadernos de arqueología de la Universidad de Navarra 24, 103-121. 